PNL-6840

UC-70

\title{
Field Study Plan for Alternate Barriers
}

H. D. Freeman

G. W. Gee

J. F. Relyea

May 1989

Prepared for the U.S. Department of Energy under Contract DE-AC06-76RLO 1830

Pacific Northwest Laboratory

Operated for the U.S. Department of Energy

by Battelle Memorial Institute 


\title{
DISCLAIMER
}

This program was prepared as an account of work sponsored by an agency of the United States Government. Neither the United States Government nor any agency thereof, nor Battelle Memorial Institute, nor any of their employees, makes any warranty, express or implied, or assumes any legal liability or responsibility for the accuracy, completeness, or usefulness of any information, apparatus, product, or process disclosed, or represents that its use would not infringe privately owned rights. Reference herein to any specific commerical product, process, or service by trade name, trademark, manufacturer, or otherwise, does not necessarily constitute or imply its endorsement, recommendation, or favoring by the United States Covernment or any agency thereof, or Battelle Memorial Institute. The views and opinions of authors expressed herein do not necessarily state or reflect those of the United States Government or any agency thereof.

\section{PACIFIC NORTHWEST LABORATORY operated by BATTELLE MEMORIAL INSTITUTE for the \\ UNITED STATES DEPARTMENT OF ENERGY under Contract DE-AC06-76RLO 1830}

\author{
Printed in the United States of America \\ Available from \\ National Technical Information Service \\ United States Department of Commerce \\ 5285 Port Royal Road \\ Springfield, Virginia 22161 \\ NTIS Price Codes \\ Microfiche A01 \\ Printed Copy
}

$\begin{array}{cc}\text { Pages } & \begin{array}{c}\text { Price } \\ \text { Codes } \\ 001-025\end{array} \\ 026-050 & \text { A02 } \\ 051-075 & \text { A03 } \\ 076-100 & \text { A04 } \\ 101-125 & \text { A05 } \\ 126-150 & \text { A06 } \\ 151-175 & \text { A07 } \\ 176-200 & \text { A08 } \\ 201-225 & \text { A09 } \\ 226-250 & \text { A10 } \\ 251-275 & \text { A11 } \\ 276-300 & \text { A12 } \\ & \text { A13 }\end{array}$




\section{FIELD STUDY PLAN FOR ALTERNATE BARRIERS}

H. D. Freeman
G. W. Gee
J. F. ReTyea (a)

May 1989

Prepared for

the U.S. Department of Energy

under Contract DE-ACO6-76RLO 1830

Pacific Northwest Laboratory

Richland, Washington 99352

(a) Westinghouse Hanford Company 



\section{SUMMARY}

Pacific Northwest Laboratory (PNL) is providing technical assistance to Westinghouse Hanford Company (WHC) in selecting, designing, evaluating, and demonstrating protective barriers. As part of this technical assistance effort, asphalt, clay, and chemical grout will be evaluated for use as alternate barriers. The purpose of the subsurface layer is to reduce the 1ikelihood that extreme events (i.e., 100-year maximum storms, etc.) will cause significant drainage through the barrier. The tests on alternate barriers will include laboratory and field analys is of the subsurface layer performance. This field test $p l$ an outlines the activities required to test and design subsurface moisture barriers. The test plan covers activities completed in FY 1988 and planned through FY 1992 and includes a field-scale test of one or more of the alternate barriers to demonstrate full-scale application techniques and to provide performance data on a larger scale.

Tests on asphalt, clay, and chemical grout were initiated in FY 1988 in smal1 (30.5 cm diameter) tube-type lysimeters. The parameters used for testing the materials were different for each one. The tests had to take into account the differences in material characteristics and response to changes in conditions, as well as information provided by previous studies.

Asphalt is suited for use as a sublayer in protective barriers since it has an extremely low permeability and resists penetration by animal and plant intrusion. In addition, asphalt is an extremely stable material when protected from ultraviolet light. This long-term stability has been demonstrated by the recovery of asphalt artifacts and pavements that have been dated from 4900 to 5500 years old. Asphalt was tested successfully by PNL as a cover system at a uranium mill tailings site in Grand Junction, Colorado. The information gained from that study is being used to evaluate barrier performance at Hanford.

Clay, with its low permeability, has been used for seepage barriers for many years. The natural plasticity of clay is an advantage for resisting a 
breach caused by subsidence of the materials underneath it. The clay liner is being evaluated in this study to determine its performance as a barrier in the arid environment at Hanford.

Chemical grouts have been used to limit water movement and to add strength to noncohesive materials. Sodium silicate, an inorganic grout, is being evaluated to determine its effectiveness with Hanford soils. This material is geochemically stable and much less toxic than organic grouts. Adding the grout to the soil at the waste site is expected to reduce hydraulic conductivity and further stabilize the barrier materials. 


\section{CONTENTS}

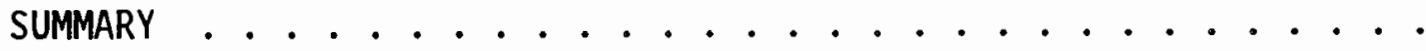

1.0 INTRODUCTION . . . . . . . . . . . . . . 1.1

2.0 TEST PLANS FOR ASPHALT BARRIERS . . . . . . . . 2.1

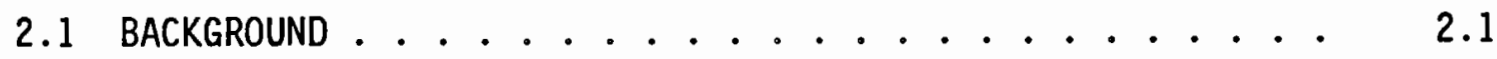

2.2 TEST OBJECTIVE AND PURPOSE . . . . . . . . . . 2.2

2.2.1 Test Description. ........... 2.3

2.3 FISCAL YEAR $1988 \ldots \ldots \ldots . \ldots . \ldots . \ldots . \ldots$

2.3.1 Laboratory Studies ........... . 2.3

2.3.2 Small-Tube Lysimeter Studies . . . . . . 2.5

2.4 FISCAL YEAR $1989 \ldots \ldots \ldots \ldots \ldots$

2.4 .1 Lysimeter Studies . . . . . . . . . 2.9

2.4.2 Long-Term Stability Tests .......... 2.9

2.4 .3 Field Tests . . . . . . . . . . . 2.9

2.5 FISCAL YEAR $1990 \ldots \ldots \ldots \ldots . \ldots \ldots$

2.5.1 Lysimeter Studies . . . . . . . . . . 2.10

2.5.2 Long-Term Stability Tests .......... 2.10

2.5 .3 Field Tests . . . . . . . . . . 2.10

2.6 FISCAL YEAR $1991 \ldots \ldots \ldots \ldots$

2.6.1 Long-Term Stability Tests .......... 2. 2.10

2.6.2 Field Tests............... 2.11

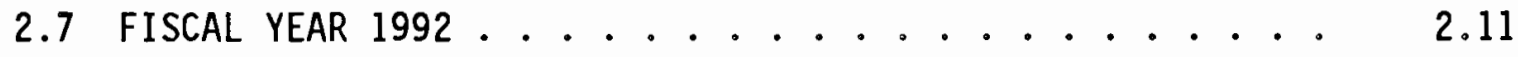

2.7.1 Long-Term Stability Tests .......... 2... 2.11

2.7 .2 Field Tests ....................... 2.11 
3.0 TEST PLANS FOR CLAY LINER . . . . . . . . . . . . . . . 3.1

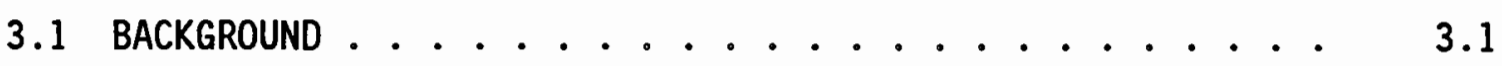

3.2 TEST OBJECTIVE AND PURPOSE . . . . . . . . . . 3.2

3.2.1 Test Description . . . . . . . . . . 3.2

3.3 FISCAL YEAR $1988 \ldots \ldots \ldots \ldots \ldots . \ldots \ldots$

3.3.1 Lysimeter Studies . . . . . . . . . . 3.3

3.4 FISCAL YEAR $1989 \ldots \ldots \ldots \ldots$

3.4.1 Lysimeter Studies . . . . . . . . . . 3.4

3.4.2 Field Studies . . . . . . . . . . 3.4

3.5 FISCAL YEAR $1990 \ldots \ldots \ldots \ldots \ldots$

3.5.1 Lysimeter Studies . . . . . . . . . 3.5

3.5 .2 Field Studies . . . . . . . . . . 3.5

3.5.3 Long-Term Stability Studies . . . . . . . 3.5

3.6 FISCAL YEAR $1991 \ldots \ldots \ldots \ldots$

3.6.1 Lysimeter Studies . . . . . . . . . . 3.6

3.6.2 Field Studies . . . . . . . . . 3.7

3.6.3 Long-Term Stability Studies . . . . . . . 3.7

3.7 FISCAL YEAR $1992 \ldots \ldots \ldots \ldots . \ldots \ldots$

3.7.1 Field Studies . . . . . . . . . . 3.7

3.7.2 Long-Term Stability Studies . . . . . . . 3.7

4.0 TEST PLANS FOR CHEMICAL GROUT . . . . . . . . . . 4.1

4.1 BACKGROUND .......................... 4.1

4.2 TEST OBJECTIVE AND PURPOSE . . . . . . . . . 4.2

4.2.1 Test Description ............ 4.2

4.3 FISCAL YEAR $1988 \ldots \ldots \ldots \ldots \ldots . \ldots \ldots . \ldots . \ldots . \ldots . \ldots$

4.3.1 Lysimeter Studies . . . . . . . . . 4.2 


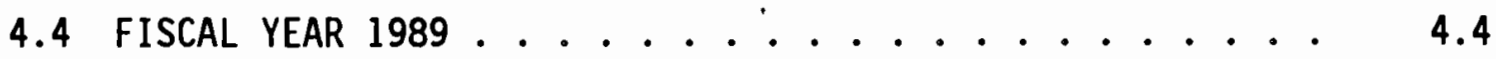

4.4.1 Lysimeter Studies . . . . . . . . . . 4.4

4.4 .2 Field Studies .............. 4.4

4.5 FISCAL YEAR $1990 \ldots \ldots \ldots . \ldots . \ldots . \ldots . \ldots$

4.5.1 Lysimeter Studies . . . . . . . . . . 4.4

4.5.2 Field Studies.............. 4.4

4.5.3 Long-Term Stability Studies . . . . . . . . 4.5

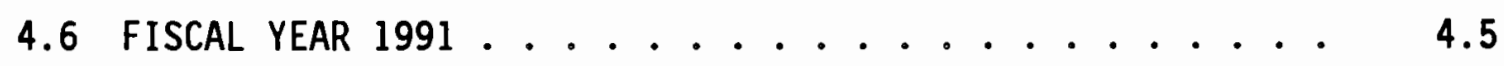

4.6.1 Lysimeter Studies . . . . . . . . . . 4.5

4.6.2 Field Studies............. . 4.5

4.6.3 Long-Term Stability Studies . . . . . . . 4.5

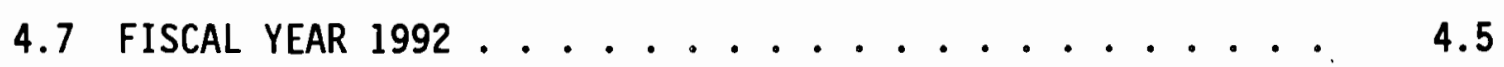

4.7.1 Field Studies............. 4.5

4.7.2 Long-Term Stability Studies . . . . . . . 4.6

5.0 COST ESTIMATES $\ldots \ldots \ldots \ldots . \ldots \ldots . \ldots \ldots$

6.0 SAFETY AND QUALITY ASSURANCE .................... 6.1

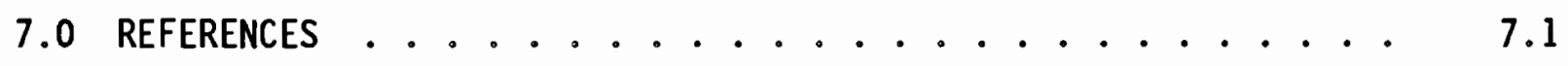




\section{FIGURES}

1.1 Cross Section of the Protective Barrier and Warning Marker System for the Hanford Site . . . . . . . . . . . . . 1.2

1.2 Cross Section of the Protective Barrier and Warning Marker System Modified to Include a Subsurface Alternate Barrier . . .

2.1 Plan View of Small-Tube Lysimeter Site and Operational Features of Lysimeters . . . . . . . . . . 2.6

2.2 Cross Section of Tube-Type Lysimeter for Asphalt Barrier Tests ................ 2.7

2.3 Plan View of Alternate Barrier Test Lysimeters Showing Treatment Combinations .............. 2.8

3.1 Test Configuration of Small-Tube Lysimeter Clay Barrier Component ..................... 3.4

3.2 Field-Scale Barrier Test Facility . . . . . . . . . 3.6

4.1 Small-Tube Lysimeter Chemical Grout Barrier Component .... 4.3

\section{$\underline{\text { TABLE }}$}

2.1 Asphalt Emulsion Mix Tests .............. 2.4 


\subsection{INTRODUCTION}

The Protective Barrier and Warning Marker System Program managed by Westinghouse Hanford Company (WHC) for the U.S. Department of Energy (DOE) is testing a multilayer earthen cover design as a long-lasting barrier to radionuclide migration at the Hanford Site. Specifically, the barrier is being developed to reduce the potential for water infiltration, plant and animal intrusion, and erosion at low-level waste disposal sites (Adams and Wing 1986). Figure 1.1 shows the basic features of the conceptual earthen cover system.

While the type of barrier system illustrated in Figure 1.1 is considered to be adequate under present climatic conditions, certain conditions (e.g., 100-year storm events) could cause excess infiltration and lead to drainage through the barrier (DOE 1987; Fayer et al. 1985; Fayer 1987). Pacific Northwest Laboratory (PNL)(a) is providing technical assistance to WHC in selecting, designing, evaluating, and demonstrating barriers that may be effective as a protective cover and last thousands of years while ensuring that infiltration and plant, animal, and human intrusion are minimized.

Figure 1.2 shows one possible modification of the Hanford Site Protective Barrier which includes a low permeability sublayer. The exact design of the subsurface layer including material type, thickness, etc., will depend on a variety of factors that are discussed below.

Three materials have been selected by the PNL and WHC barrier team as potential materials to use in a low-permeability control layer for the Hanford Site Protective Barrier. These materials are asphalt, clay (bentonite), and chemical grout (sodium silicate). While numerous materials could have been selected, these materials represented a good cross section of materials that have been used at other waste sites; they are long lasting and can be obtained readily from commercial sources. In addition, PNL has tested asphalts and clays as liner materials for barrier systems at uranium mill tailings sites (Baker et a1. 1984; Buelt 1983; Freeman, Hartley, and

(a) Operated for the U.S. Department of Energy by Battelle Memorial Institute. 
i

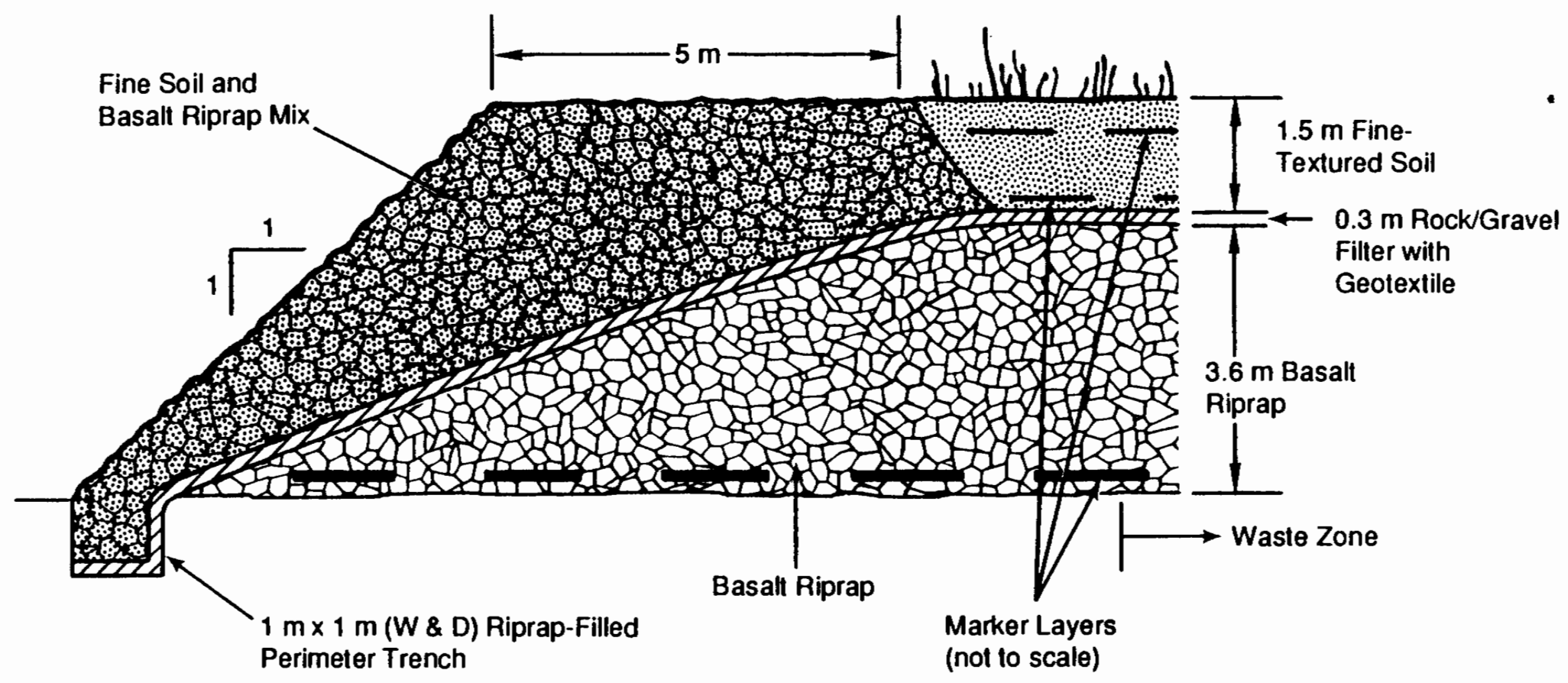

FIGURE 1.1. Cross Section of the Protective Barrier and Warning Marker System (conceptual design) for the Hanford Site 


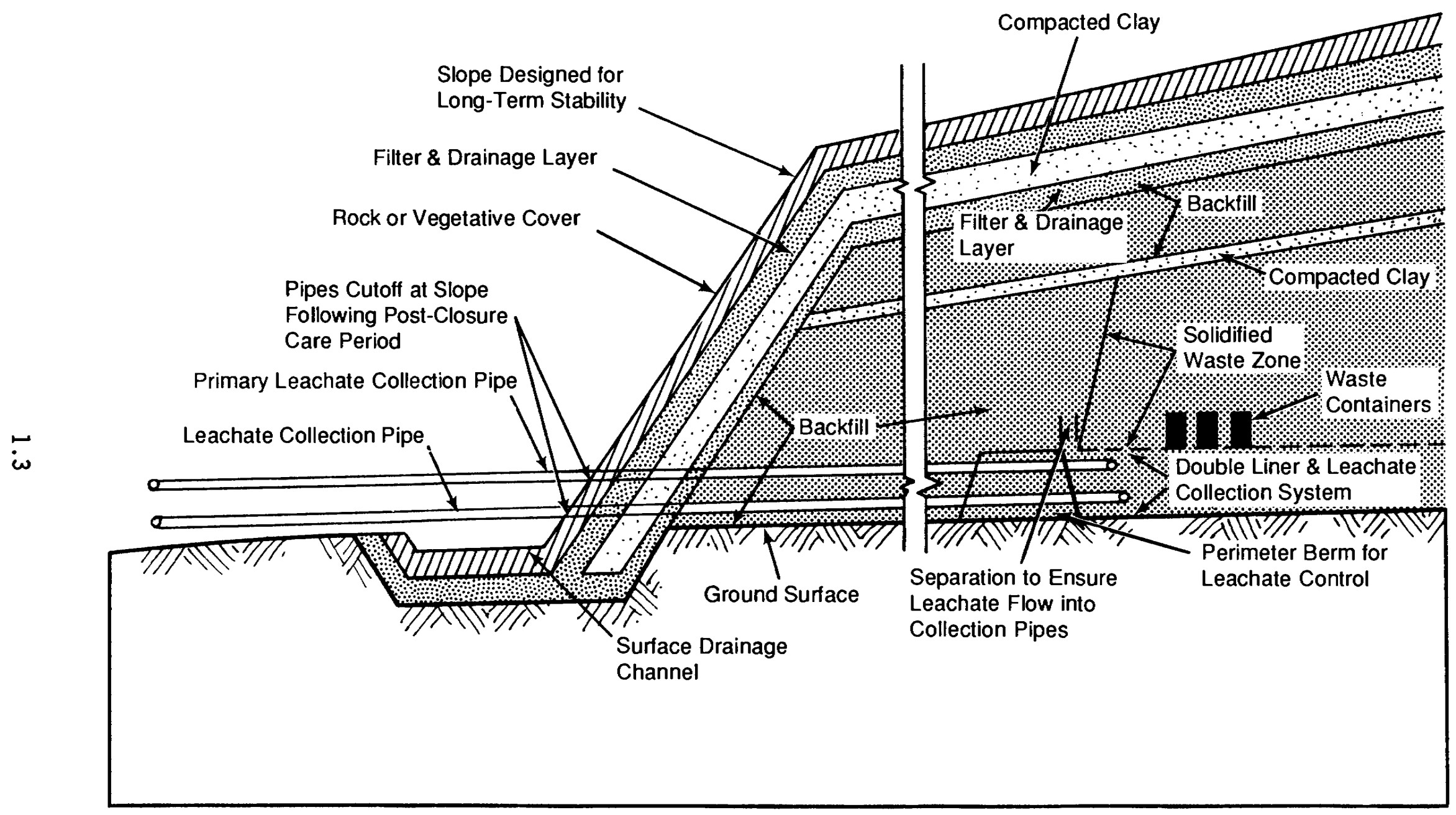

FIGURE 1.2. Cross Section of the Protective Barrier and Warning Marker System Modified to Include a Subsurface Alternate Barrier 
Gee 1984; Gee et a1. 1981; Koehmstedt, Hartley, and Davis 1977). This experience has been helpful in assessing potential materials for subsurface liners at Hanford waste sites.

Asphalt was used by early man as a paving material, wood preservative, sealant, adhesive, and mortar (LeMaire 1953; Marschner 1980 and Micropaedia 1974). Furthermore, many artifacts dating from 4900 to 5500 years old have been recovered in the Middle East in excellent condition. These artifacts attest to the long-term stability of asphalt under anaerobic conditions.

Clay (bentonite) and grout (sodium silicate) are inorganic materials that can be found in nature, and are relatively stable. Bentonite is one of the most commonly used materials for lining waste sites and has also been recommended by the U.S. Environmental Protection Agency (EPA) and others (Herzog et al. 1982; NRC-EPA 1987) as a sublayer in cover systems. Specific details on types of clays used in these waste disposal facilities are lacking, and only general guidelines such as permeability limits have been issued (EPA 1978).

This report describes the field plans developed for testing asphalt, clay, and grout. While all three materials are being evaluated for use as a subsurface layer, the individual tests vary. For example, asphalt is being tested with vegetation to determine the effects of root penetration. Vegetation is not included in the clay and grout studies because the tests focus on drainage. The information discussed here covers the work conducted during FY 1988 and the activities planned through FY 1992. Cost estimates and safety and quality assurance procedures are also given. 


\subsection{IEST PLANS FOR ASPHALT BARRIERS}

\subsection{BACKGROUND}

The use of asphalt emulsions as a thin radon barrier layer initially was demonstrated by PNL in 1976 (Koehmstedt, Hartley, and Davis 1977). However, this thin seal did not have suitable mechanical stability for use as a longterm barrier. In 1979, the study of asphalt radon barriers was reactivated under DOE's Uranium Mill Tailings Remedial Action Program (UMTRAP) (Hartley et al. 1980). During the summer of 1979 the first admix barrier design was tested on a large scale at the Grand Junction Tailings Pile, Colorado. The admix seal consisted of asphalt emulsion mixed in situ with uranium mill tailings. This seal produced variable results because of the heterogeneous nature of the tailings. The wide range in particle size and moisture content encountered in the test area caused variations in the coating of the particles, and, hence, produced an inferior seal. The barrier formulation subsequently was changed (in 1980) (Hartley et al. 1983).

The radon barrier work continued in 1980, including another large-scale field test designed to compare a number of barrier formulations and application techniques. The techniques included in situ application, pugmill/paver, hot rubberized asphalt, and cold mix paver. The most desirable seals were produced with the cold mix paver, available commercially, which used concrete sand as the aggregate in the seal instead of relying on the heterogeneous tailings.

The asphalt seal tested in 1980 contained approximately 22 wt\% residual asphalt, enough to completely fill the voids of the aggregate. This asphalt produced an extremely tight seal with a very low diffusion coefficient for radon $\left(<10^{-6} \mathrm{~cm}^{2} / \mathrm{s}\right)$. An area of over $3400 \mathrm{~m}^{2}$ was covered using this technique, which gave a good indication of seal performance on a large scale. On the average, greater than $99.5 \%$ radon flux reduction was found for the cold mix paver seal (Hartley et a1. 1981). Recent monitoring of this seal by Gee et al. (1989) and Karp (1986) has shown it to be as effective as originally measured. 
In 1981, a third large-scale test area on the Grand Junction Tailings Pile was covered with an asphalt barrier. The cold mix paver method was again used. The purpose of this test was to compare three radon barrier techniques: earthen covers; multilayer clay barriers; and asphalt emulsion barriers. Subsequent radon flux monitoring has shown that the asphalt seal was very effective in reducing radon emissions from the tailings (Hartley et a1. 1982, 1983). Measurements taken from 1981 through 1987 showed low radon flux levels. Only one measurement within the borders of the plot showed radon flux levels above the EPA 1 imit of $20 \mathrm{pCi} \mathrm{m}^{-2} \mathrm{~s}^{-1}$ (Gee et al. 1989; Karp 1986). The results from the 1980 and 1981 plots indicate that asphalt barriers can effectively retard vapor migration; thus, it is expected that water infiltration should be minimal in this material. Costs of the asphalt barrier system were found to be comparable with earthen $\mathrm{fill}$ and less expensive than clay liner systems (Baker et al. 1982). The large-scale field tests at Grand Junction demonstrated the practicability of asphalt barriers and were used as the basis for selecting asphalt to be tested under Hanford Site conditions.

\subsection{TEST OBJECTIVE AND PURPOSE}

The purpose of the asphalt testing is to evaluate the use of asphaltbased materials as components of protective barriers for low-level waste disposal sites at Hanford. The primary emphasis is to evaluate the applicability of the UMTRAP technology to the Hanford Site. The asphalt seals initially were tested in the laboratory. Promising materials are being demonstrated on a slightly larger scale using small-tube lysimeters $130.5 \mathrm{~cm}$ diameter). If successful, the barrier will be demonstrated on a much larger scale similar to the tests performed on the Grand Junction Tailings Pile. This larger-scale demonstration is necessary to evaluate cost-effective application techniques and to develop quality assurance techniques for monitoring the installation of these barriers. Optimization of asphalt barriers (e.g., determining asphalt content and thickness) is required to produce the most cost-effective barrier for the intended purpose. 


\subsubsection{Test Description}

The asphalt barrier studies are divided into three categories: 1) 1aboratory studies, 2) lysimeter studies, and 3) field demonstration. Work in FY 1988 focused on the first two categories, while later work will contain elements of all three categories. The work for FY 1988 is detailed below. Activities for FY 1989 through FY 1992 are described but will be detailed more thoroughly in future test plans.

\subsection{FISCAL YEAR 1988}

\subsubsection{Laboratory Studies}

The purpose of the laboratory studies in FY 1988 was to formulate two asphalt barriers for use in small-tube 1ysimeter tests. Laboratory tests were conducted to determine the optimum parameters for a successful asphalt barrier. Parameters that were investigated included aggregate type, asphait emulsion type, aggregate moisture content, and amount of asphalt in the asphalt/aggregate admix.

For testing asphalt barrier formulations, a mixer was used to prepare small asphalt samples $(-10 \mathrm{~cm}$ diameter $)$. The mixture was then compacted in steel molds with a hydraulic press. Compacted sample dimensions were approximately $10 \mathrm{~cm}$ in diameter by $4 \mathrm{~cm}$ thick. Samples were tested for hydraulic conductivity by using a pressurized permeameter. The hydraulic conductivity is used as the measure of success of the admix formulation. The hydraulic conductivity limit is set at a value of $10^{-9} \mathrm{~cm} / \mathrm{s}$.

Two different aggregate sources were used in the mix design: concrete sand obtained from near the 200 Area and natural blow sand from near the 200 Area lysimeter test site. The concrete sand represented an aggregate source that must meet certain specifications. The blow sand represented a "free" source of aggregate that could result in a lower cost barrier. Since each aggregate will require a different asphalt emulsion formulation for optimum barrier performance, two different asphalt emulsions were tested. The most suitable emulsion for each aggregate source was tested by Akzo Chemie America, an emulsifier manufacturer. The tests indicated that an emulsion with a $+25 \mathrm{mV}$ charge was most suitable for the blow sand and 
an emulsion with a $+78 \mathrm{mV}$ charge was most suitable for the concrete sand. This information was used to produce the experimental design outlined in Table 2.1. Each sample was prepared in duplicate to ensure more confidence in test results. Problems in trimming the asphalt samples to fit the permeameter cells prevented valid results from being obtained for all of the tests outlined in Table 2.1. Later modification of the procedure to mold the asphalt directly in the permeameter cells resulted in hydraulic conductivity measurements of $<10^{-14} \mathrm{~cm} / \mathrm{s}$ for seals containing $24 \mathrm{wt} \%$ asphalt. Additional tests using the modified procedure are being conducted in FY 1989 for seals containing 18, 20, and 22 wt\% asphalt.

An asphalt-based material used in pond liners also has shown promise as an effective barrier material. This material is composed of a styrenebutadiene asphalt material, which was tested at Grand Junction with some

TABLE 2.1. Asphalt Emulsion Mix Tests

Test ID Aggregate Moisture Content Emulsion Asphalt Content

Effect of Moisture Content

$\begin{array}{lllll}\text { HPB-01 } & \text { Blow Sand } & \text { Oven Dried } & +25 \mathrm{mV} & 16 w t \% \\ \text { HPB-02 } & \text { Concrete Sand } & \text { Oven Dried } & +78 \mathrm{mV} & 16 w t \% \\ \text { HPB-03 } & \text { Blow Sand } & 2 \mathrm{wt} \% & +25 \mathrm{mV} & 16 w t \% \\ \text { HPB-04 } & \text { Concrete Sand } & 2 \mathrm{wt} \% & +78 \mathrm{mV} & 16 w t \% \\ \text { HPB-05 } & \text { Blow Sand } & 4 w t \% & +25 \mathrm{mV} & 16 w t \% \\ \text { HPB-06 } & \text { Concrete Sand } & 4 w t \% & +78 \mathrm{mV} & 16 w t \%\end{array}$

Effect of Asphalt Content

$\begin{array}{lllll}\text { HPB-07 } & \text { Blow Sand } & \text { Optimum }(a) & +25 \mathrm{mV} & 10 \mathrm{wt} \% \\ \text { HPB-08 } & \text { Concrete Sand } & \text { Optimum } & +78 \mathrm{mV} & 10 \mathrm{wt} \% \\ \text { HPB-09 } & \text { Blow Sand } & \text { Opt imum } & +25 \mathrm{mV} & 12 \mathrm{wt} \% \\ \text { HPB-10 } & \text { Concrete Sand } & \text { Opt imum } & +78 \mathrm{mV} & 12 \mathrm{wt} \% \\ \text { HPB-11 } & \text { Blow Sand } & \text { Opt imum } & +25 \mathrm{mV} & 18 \mathrm{wt} \% \\ \text { HPB-12 } & \text { Concrete Sand } & \text { Optimum } & +78 \mathrm{mV} & 18 \mathrm{wt} \%\end{array}$

Effect of Asphalt Type at Optimum Conditions

$\begin{array}{lllll}\text { HPB-13 } & \text { Blow Sand } & \text { Optimum } & +78 \mathrm{mV} & \text { Optimum (b) } \\ \text { HPB-14 } & \text { Concrete Sand } & \text { Optimum } & +25 \mathrm{mV} & \text { Optimum }\end{array}$

(a) Optimum moisture content found in Tests 1-6.

(b) Optimum asphalt content found in Tests 7-12. 
success. The material is extremely resistant to puncture and retains its flexibility over a wide temperature range. Because of its very elastic properties it is referred to as rubberized asphalt. The relative effectiveness of this material was also tested in the laboratory by measuring the hydraulic conductivity of a sample sent from the manufacturer. Hydraulic conductivity tests showed that the material has a hydraulic conductivity $<10^{-12} \mathrm{~cm} / \mathrm{s}$.

\subsubsection{Small-Tube Lysimeter Studies}

The purpose of the lysimeter tests is to evaluate the performance of asphalt barrier formulations under environmental conditions. The major focus of the investigation is the effect of water infiltration and plant intrusion on seal integrity.

Eight small-tube (30.5 cm diameter) weighing lysimeters were installed at the south end of the Smal1 Tube Lysimeter Facility (STLF) adjacent to the Field Lysimeter Test Facility (FLTF) located near the 200 Area Hanford Meteorological Station (HMS) (Figure 2.1). Two control lysimeters had been installed earlier as part of another program (Gee, Downs, and Rockhold (1989).

Two different asphalt barrier treatments are being tested in duplicate. Each treatment is being tested with and without vegetation. The treatments were selected based on the results of the laboratory hydraulic conductivity studies. Figure 2.2 shows schematically the cross section of a lysimeter used to test asphalt. The bottoms of the lysimeters were filled with $\sim 15 \mathrm{~cm}$ of gravel to facilitate collection of any moisture drainage. The gravel was covered with $5 \mathrm{~cm}$ of coarse soil. An asphalt barrier, $-1 \mathrm{~cm}$ thick for rubberized asphalt and $\sim 15 \mathrm{~cm}$ for admix containing $24 \mathrm{wt} \%$ asphalt, was placed on the coarse soil. The asphalt barrier was covered with an additional 1 to $1.2 \mathrm{~m}$ of sand. Fifteen centimeters of gravel were $\mathrm{placed}$ on the surface to enhance water infiltration by 2 to 5 times the infiltration of uncovered soils. Half of the lysimeters were seeded with cheatgrass (Bromus tectorum) and Russian thistle (Salsola kali), also called tumbleweed, to assess the effect of vegetation on the barrier. Figure 2.3 shows the arrangement of the duplicate test lysimeters in the test facility. 


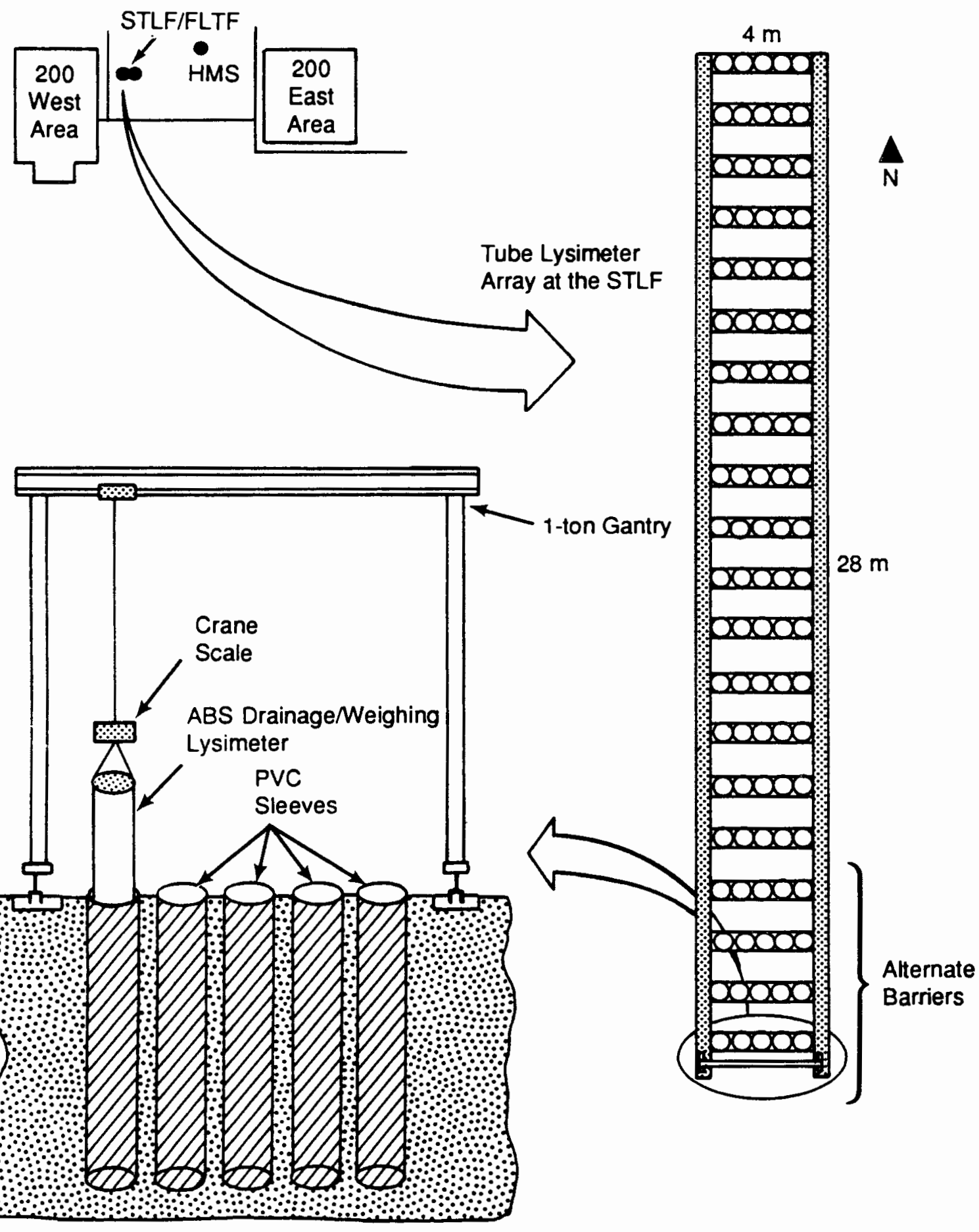

FIGURE 2.1. Plan View of Small-Tube Lysimeter Site and Operational Features of Lysimeters 


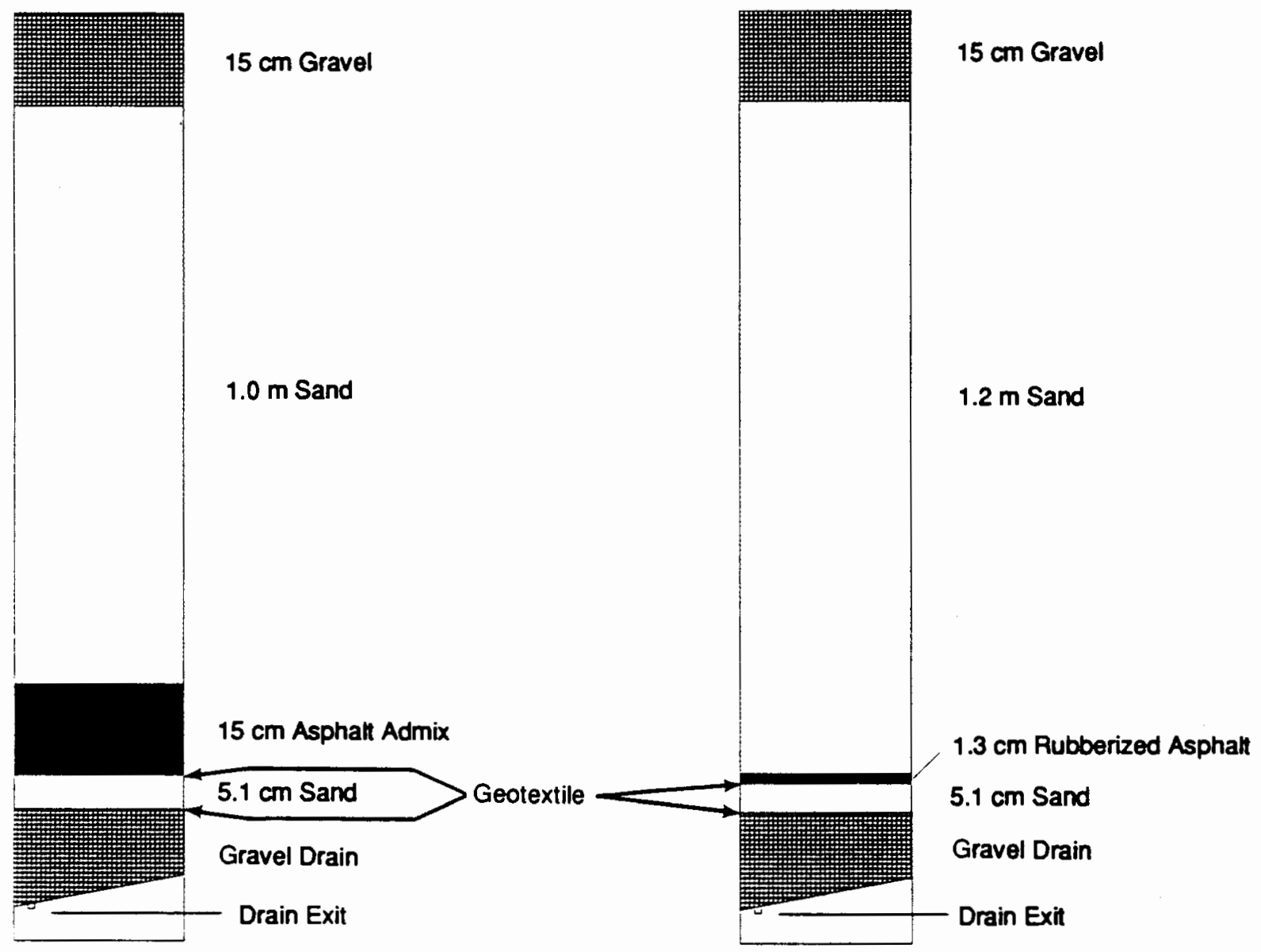

FIGURE 2.2. Cross Section of Tube-Type Lysimeter for Asphalt Barrier Tests

The effectiveness of the barriers is being assessed by closely monitoring the water balance of the lysimeters. The lysimeters are removed periodically from the racks and checked for moisture drainage through a drain port in the bottom. After the first year there should be a quasi-equilibrium on the bare soil plots that are covered with gravel. The drainage is expected to amount to less than $0.05 \mathrm{~cm} /$ year. Drainage from the bottom of the 1ysimeter can be measured with a precision of less than $0.01 \mathrm{~cm}$ (resolution $<5 \mathrm{~mL})$. 


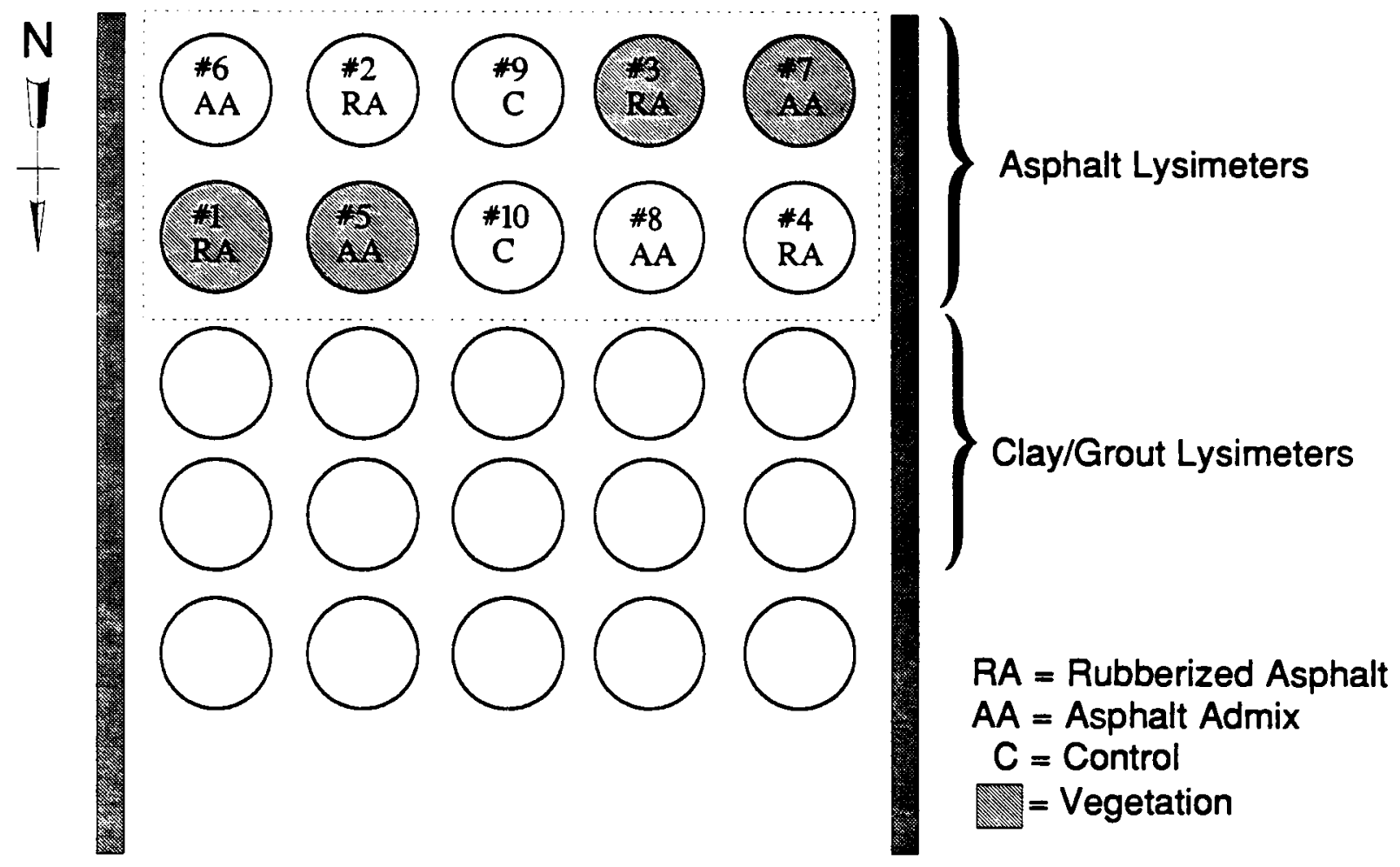

FIGURE 2.3. Plan View of Alternate Barrier Test Lysimeters Showing Treatment Combinations

Total water stored in the lysimeter is determined periodically by using a crane scale to weigh the lysimeter. Total water input is determined from meteorological data from the nearby HMS. Evapotranspiration is computed as the difference between the water input and water stored in the lysimeters.

The relatively shallow soil cover will allow the effects of root penetration through the seal to be studied. Cheatgrass roots can be expected to penetrate up to $75 \mathrm{~cm}$, while Russian thistle has roots that can extend several meters. Incorporating several plant species into the lysimeters will allow us to test for root penetration from one or more of the plant species. After several years of monitoring, one replicate from each treatment will be split lengthwise for examination. Soil moisture profiles, degree of root penetration, and condition of sea 1 will a 11 be noted. The remaining set of lysimeters will be monitored for several more years. 


\subsection{FISCAL YEAR 1989}

The studies for FY 1989 are focusing on identifying the proper engineering parameters for designing a complete barrier system. These parameters include mechanical properties, long-term stability, equipment requirements, material specifications, quality assurance issues, and cost estimates. The primary activities being conducted in FY 1989 are continuation of lysimeter monitoring and preliminary planning for a field demonstration.

\subsubsection{Lysimeter Studies}

The smal1-tube lysimeters installed in FY 1988 are being monitored on a monthly basis. Russian thistle has been planted on half of the asphalt lysimeters.

\subsubsection{Long-Term Stability Tests}

Issues related to the long-term stability of asphalt barriers are being identified to provide a basis for planning for laboratory and field testing in FY 1990 and beyond. Parameters that may be of importance include oxidation, temperature effects, and mechanical stability.

\subsubsection{Field Tests}

An important element in designing the complete barrier system is the use of large-scale field testing to develop data required for cost estimation, quality assurance planning, and equipment selection and operation. The planning and coordination required for a successful field test will be initiated in FY 1989 so that the test itself can be conducted in the latter part of FY 1990. Planning will include site selection and preliminary design and development of a draft test $\mathrm{plan}$, including costs.

\subsection{FISCAL YEAR 1990}

The activities planned for FY 1990 include continuation of the lysimeter tests, initiation of long-term stability tests, and initiation of the largescale field testing. 


\subsubsection{Lysimeter Studies}

The smal1-tube lysimeters will continue to be monitored to obtain water balance data.

\subsubsection{Long-Term Stability Tests}

A number of stability tests designed to address any long-term stability questions identified in FY 1989 will be initiated. These tests will be designed to accelerate the rate of degradation to allow long-term projections of the seal integrity and effectiveness to be made.

\subsubsection{Field Tests}

The primary emphasis for FY 1990 will be the planning and installation of a large-scale field test of the most successful asphalt barrier design. Based on present recommendations (NRC-EPA 1987), the asphalt sublayer would satisfy Resource Conservation and Recovery Act (RCRA) requirements by providing an "impermeable" cover over the waste. The purpose of the test will be to obtain data on installation techniques, application costs, quality control issues, and barrier effectiveness. The test will be conducted using full-scale equipment covering a large area $\left(-3000 \mathrm{~m}^{2}\right)$ to obtain information on application rates, seam integrity, and variability in seal thickness and quality. The seal will be thoroughly characterized to provide data useful in predicting barrier effectiveness and for developing quality control procedures. The barrier will be monitored for a minimum of 2 years to allow plant and animal intrusion to be studied. In addition, failure mechanisms such as subsidence-related stresses can be simulated by inducing subsidence by artificial means.

\subsection{FISCAL YEAR 1991}

\subsubsection{Long-Term Stability Tests}

Laboratory tests initiated in FY 1990 will be continued to obtain data necessary to predict performance of the barrier for the required performance period. 


\subsubsection{Field Tests}

The effectiveness of the large-scale field tests installed in FY 1990 will be monitored.

\subsection{FISCAL YEAR 1992}

\subsubsection{Long-Term Stability Tests}

Long-term stability tests will be completed in FY 1992. Results of this monitoring will be used to predict the long-term performance of the barriers with regard to degradation. A topical report summarizing all long-term stability studies will be prepared.

\subsubsection{Field Tests}

The field tests will continue to be monitored throughout the year to allow an additional growing season to be assessed. Plant and animal intrusion will be closely monitored to determine if the barrier is breached. 



\subsection{TEST PLANS FOR CLAY LINER}

\subsection{BACKGROUND}

Clay is a natural soil material that is low in permeability. Most particle sizes are less than $5 \mu \mathrm{m}$ in diameter. The low permeability and natural plasticity of clay make it suitable for study as a component of protective barriers at the Hanford Site. However, the performance of clay in arid environments needs to be further investigated.

Clay materials have been used for many years as seepage barriers for reservoirs, canals, waste landfills, and impoundments, and as liners and covers for waste sites (Daniel 1987; Daniel and Trautwein 1986; Day and Daniel 1985; Ely et al. 1983). Furthermore, clay materials have existed for many thousands of years at temperatures less than $100^{\circ} \mathrm{C}$ (Pusch 1983). Because of its plasticity, a clay layer would also be expected to resist a breach caused by subsidence of the material stored below it. However, the effectiveness of liners or covers containing clay in limiting infiltration or seepage depends on many factors, including clay type, amount of admix, initial moisture contents, compactive effort, drying of the mixture during construction, soil solution chemistry, and climatic variables. Because of these factors, EPA (1978) has provided criteria for soils (clay) to be used for liner materials.

Specifically, soil used as liner/cap material must meet the following requirements :

1. must be Classified as $\mathrm{CL}, \mathrm{CH}, \mathrm{SC}$, or $\mathrm{OH}$ under the Unified Soil Classification System

2. must allow greater than $30 \%$ passage through a No. 200 sieve

3. must have a liquid limit equal to or greater than 30 units

4. must have a plasticity greater than or equal to 15 units

5. must have a $\mathrm{pH}$ of 7 or greater

6. must have a permeability of less than $10^{-7} \mathrm{~cm} / \mathrm{s}$. 
The EPA mandates the use of a clay liner/cap for landfill-type facilities. However, poor construction quality assurance (CQA) often has lead to measurements of unusually high hydraulic conductivity values (compared with values measured in laboratory tests) (Daniel 1987; Day and Daniel 1985). The factors affecting the hydraulic conductivity of a clay liner/cover can be controlled by establishing construction criteria that would use test pads to develop mixing, compaction, and testing procedures (Daniel 1987).

Hydraulic conductivity values below $10^{-10} \mathrm{~cm} / \mathrm{s}$ were measured in the laboratory by $\mathrm{K} 1 \mathrm{eppe}$ and 01 son (1985) on samples made with $12 \%$ bentonite and $88 \%$ silty sand. Carlson (1986) found that conductivity values between $10^{-10}$ and $10^{-9} \mathrm{~cm} / \mathrm{s}$ were achievable on laboratory samples with a $25 \%$ bentonite $/ 75 \%$ crushed basalt mixture. Dry bentonite absorbs water from a humid atmosphere and will swell as the humidity is increased. A layer of bentonite clay mixed with soil as a barrier component will remain "wet" as long as it is not directly exposed to surface conditions ( $1 \mathrm{~m}$ of sand or soil should be sufficient to allow the bentonite to remain moist). Compacted soil/bentonite liners and covers with hydraulic conductivities on the order of $10^{-9} \mathrm{~cm} / \mathrm{s}$ should be practical with proper field testing and CQA.

\subsection{TEST OBJECTIVE AND PURPOSE}

The purpose of the clay barrier component testing is to evaluate the use of clay materials as components of protective barriers for low-level waste disposal sites at Hanford. The objectives of this testing program are to 1) obtain practical answers to questions relating to clay-layer performance (i.e., mean hydraulic conductivity, density and strength values, and their respective variances); 2) develop methods for barrier construction in the field; and 3) develop methods for CQA to ensure that desired performance is achieved.

\subsubsection{Test Description}

The clay barrier component tests are divided into three categories: 1) lysimeter studies, 2) field studies, and 3) long-term stability studies. 
The work for FY 1988 is detailed below. Activities for FY 1989 through FY 1992 are described but will be detailed more thoroughly in future test plans.

Based on experience of WHC Environmental Technology personnel and the literature cited in Section 3.1, a mixture of $25 \%$ bentonite and $75 \%$ McGee soil is being used for the clay barrier component. This mixture was compacted at approximately $18 \%$ moisture by weight [based on experience backfilling the FLTF lysimeters with McGee soil and the bentonite compaction curves (Carlson 1986)]. The 25\% bentonite is sufficient to ensure that the mixture has the properties of a $\mathrm{clay}$, and, at the same time, reduces the amount of clay required for a barrier component by $75 \%$, compared with pure bentonite. Tests conducted with clay barrier components have a minimum overburden of $120 \mathrm{~cm}$ of soil to prevent desiccation cracking of the clay.

\subsection{FISCAL YEAR 1988}

\subsubsection{Lysimeter Studies}

The purpose of the lysimeter tests is to evaluate the performance of a clay barrier component under field conditions. Five small-tube lysimeters were installed at the south end of the STLF to test the clay component. The control lysimeters (no clay component) for these tests were already established within the STLF.

Figure 3.1 shows the test configuration. A $15-\mathrm{cm}$-thick coarse layer of pit run gravel (less than $3-\mathrm{cm}-$ diameter rock) was placed in the bottom of the lysimeter and covered with a $30-\mathrm{cm}$ layer of the clay-soil mixture. The clay layer was hand-tamped to $95 \%$ of Proctor density at or above optimum moisture content and covered with a $120-\mathrm{cm} 1$ ayer of $100 \%$ McGee soil to the top of the lysimeter. The lysimeters are bare (no vegetation) and are being irrigated as needed to maintain twice the average annual rainfall (2X normal precipitation). The lysimeters periodically are weighed and the drainage measured to determine barrier performance. 


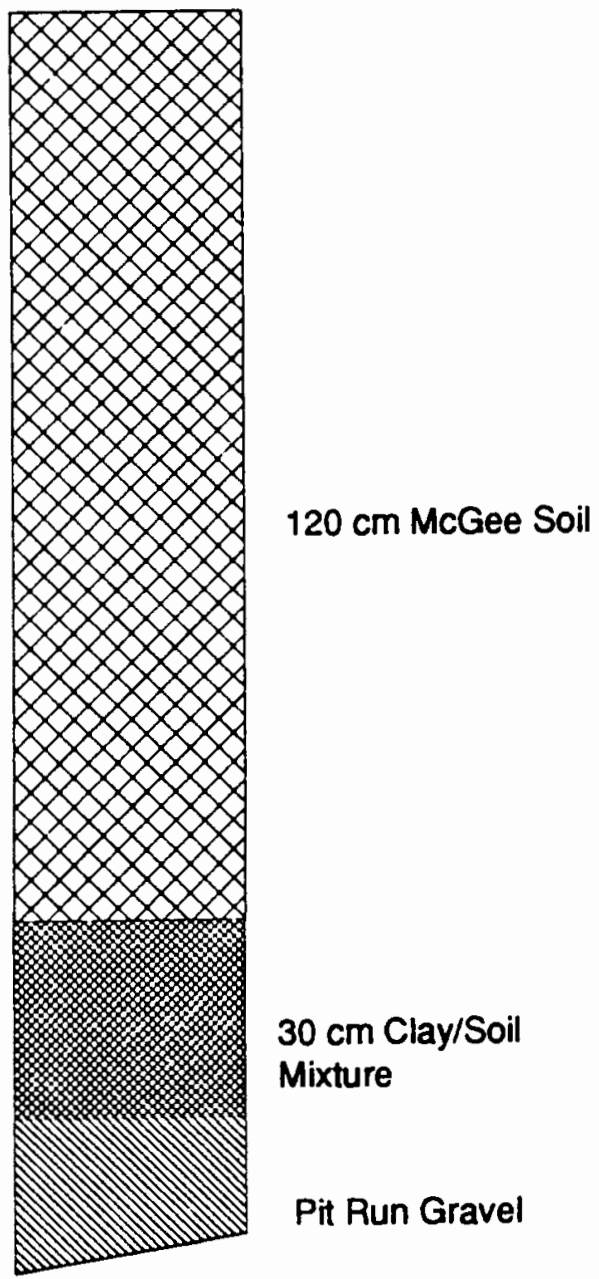

FIGURE 3.1. Test Configuration of Sma11-Tube Lysimeter Clay Barrier Component

\subsection{FISCAL YEAR 1989}

\subsubsection{Lysimeter Studies}

The smal1-tube lysimeters installed in FY 1988 are being monitored to obtain the water balance data required for barrier evaluation.

\subsubsection{Field Studies}

Small-scale field plots $\left(25 \mathrm{~m}^{2}\right)$ will be constructed to 1$)$ test the formulation of the clay-soil mixture developed in FY 1988 and 2) develop the test methods subsequently required. The construction of the plots is similar to the layering $\mathrm{placed}$ in the small-tube lysimeters, except that a layer of sand or gravel will be placed directly on top of the clay-soil layer to facilitate 
excavation for testing. Equipment and methods for obtaining sample cores will be tested in addition to laboratory testing of the cores themselves. The capability to measure in situ hydraulic conductivity with large, double-ring infiltrometers is also being developed. Measurements will be compared with similar measurements made with core samples in the laboratory.

\subsection{FISCAL YEAR 1990}

\subsubsection{Lysimeter Studies}

The small-tube lysimeters installed in FY 1988 will continue to be monitored to obtain the water balance data required for barrier evaluation.

\subsubsection{Field Studies}

A field-scale barrier (Figure 3.2) will be constructed using normal heavy construction equipment to develop construction methods and clay barrier component CQA test methods (e.g., large, double-ring infiltrometer for measuring hydraulic conductivity in the field). We anticipate constructing a 12-in. $(30-\mathrm{cm})$ clay barrier component layer in the field in two lifts. Ceramic suction devices will be placed both above and below the clay layer to detect possible moisture breakthrough. Five large-scale hydraulic conductivity tests will be conducted on the clay component immediately after construction. Six to twelve inches (15 to $30 \mathrm{~cm}$ ) of sand will be placed over the clay component before the overburden of soil is placed. A minimum of five additional field hydraulic conductivity measurements will be made on various parts of the barrier after construction to evaluate the effects of placing an overburden on the layer, along with construction performance and spatial variability of the clay component. After each hydraulic conductivity test, core samples will be taken from the immediate area to measure density and strength. Core holes will be backfilled by hand with material identical to that taken out while placing neutron-gamma access tubes to monitor moisture and density changes in the barrier.

\subsubsection{Long-Term Stability Studies}

Instrumentation $\mathrm{placed}$ in the FY 1990 field study barrier will be monitored to establish a baseline in barrier moisture and density values. 

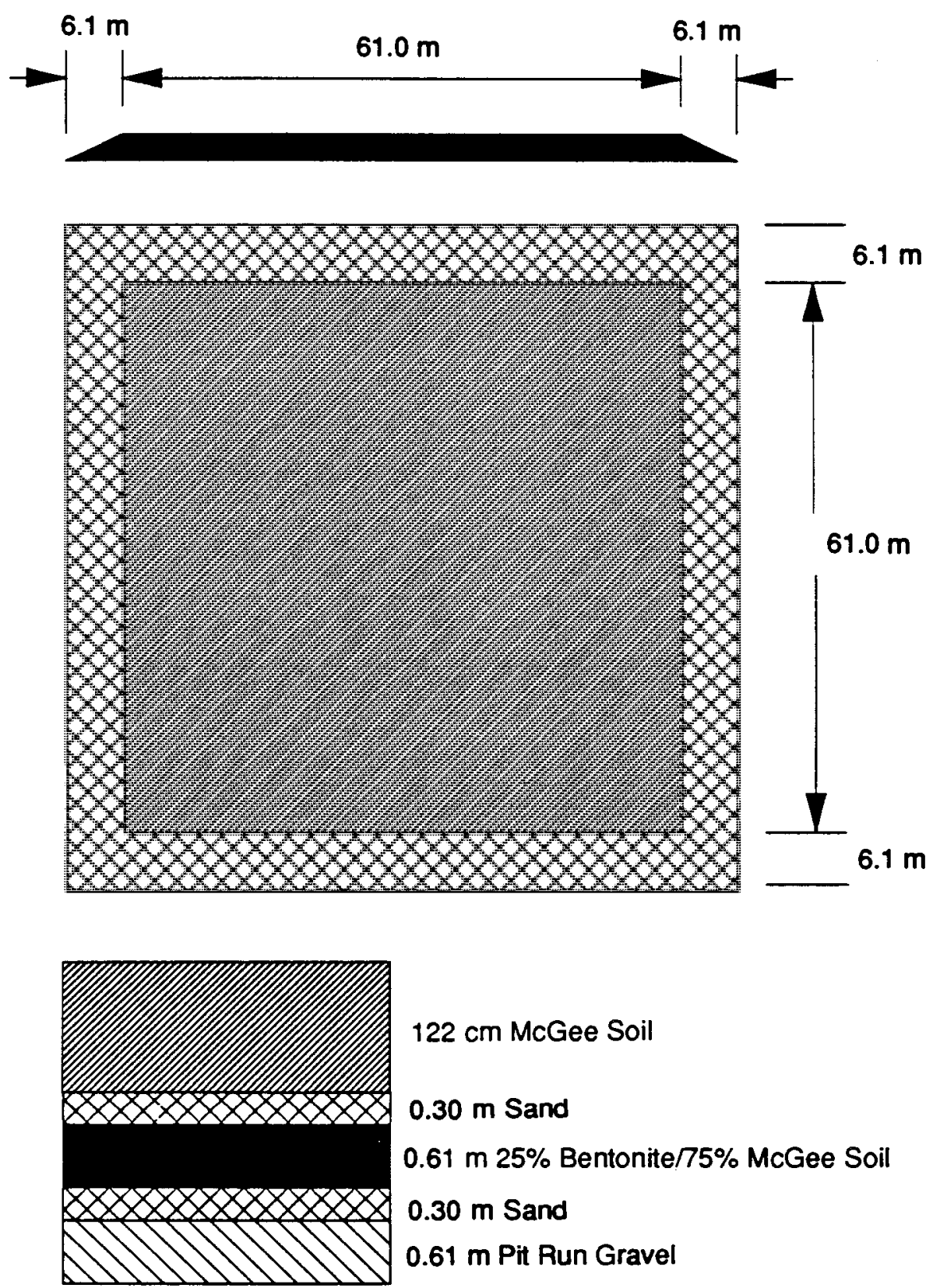

\section{FIGURE 3.2. Field-Scale Barrier Test Facility}

\subsection{FISCAL YEAR 1991}

\subsubsection{Lysimeter Studies}

The small-tube lysimeters installed in FY 1988 will continue to be monitored to obtain the water balance data required for barrier evaluation. 


\subsubsection{Field Studies}

Data from the FY 1990 field study and design criteria developed in this program will be used to construct a prototype barrier similar to that described in Section 3.5.2. Hydraulic conductivity, density, and strength measurements will also be conducted as above.

\subsubsection{Long-Term Stability Studies}

Instrumentation placed in the FY 1990 field study barrier will be monitored for significant changes in barrier moisture and density values. The clay component will be excavated to inspect the surface for possible cracks or deformations. After the inspection, hydraulic conductivity tests and coring for strength and density measurements will be conducted. The clay component will be restored for continued long-term testing.

\subsection{FISCAL YEAR 1992}

\subsubsection{Field Studies}

Construction methods and CQA tests developed in FY 1990 and 1991 will be incorporated into the construction of a large-scale barrier field study. The barrier field study facility will be used to test the effects of subsidence on clay barrier components as well as to gather data for calibration and validation of computer transport models, plant root and animal intrusion tests, erosion studies, and barrier performance demonstration.

\subsubsection{Long-Term Stability Studies}

Instrumentation placed in the FY 1990 field study barrier will be monitored for significant changes in barrier moisture and density values. The clay component will be excavated to inspect the surface for possible cracks or deformations. After the inspection, hydraulic conductivity tests and coring for strength and density measurements will be conducted. 


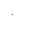

. 


\subsection{TEST PLANS FOR CHEMICAL GROUT}

\subsection{BACKGROUND}

Little is known about the use of grouts as barrier components for arid sites. Engineering grouting techniques, however, have been used in a host of environmental applications to limit water movement and to add strength to noncohesive materials. These applications include dam seepage shutoff, earth stabilization for water control and construction, stabilization of sandy formations for construction of tunnels, and sanitary landfill stabilization leaching control (Berry 1982; Caron 1982; Clarke 1982). Hartley et al. (1982) reported the use of a variety of chemical grouts to lower the permeability of uranium mill tailings. Five grouting materials were applied to tailings taken from Shiprock, New Mexico, in laboratory tests for hydraulic conductivity. Of the materials tested, a $40 \%$ sodium silicate solution lowered the hydraulic conductivity of the tailings by over 3 orders of magnitude (from $6 \times 10^{-3}$ down to $10^{-6} \mathrm{~cm} / \mathrm{s}$ ). Two organic grouts lowered the hydraulic conductivity more than the sodium silicate; however, the longevity of the performance of these materials is questionable.

Because the sodium silicate is an inorganic material, geochemically stable, and much less toxic than organic chemical grout materials, it has the advantage of greatly increasing the strength of noncohesive soils and building materials. Consequently, sodium silicate is being tested as a chemical grouting agent in this study.

Adding sodium silicate chemical grout to the top layer of silty McGee soil above the graded filter or to the fine sandy material forming the lower interface of the capillary break is expected to consolidate this layer as well as greatly reduce its hydraulic conductivity. The consolidation will prevent sifting of fine sand into the coarser material below and thus aid in maintaining performance of the capillary break for long time periods. This barrier component is expected to eliminate the need for organic-based geotextiles, which have unknown (but likely short) life expectancies for the time scales under consideration. 


\subsection{IEST OBJECTIVE AND PURPOSE}

The purpose of the chemical grout barrier component testing is to evaluate the use of chemical grout materials as components of protective barriers for low-level waste disposal sites at Hanford. The objectives of this testing program are to 1) obtain practical answers to questions relating to chemical grout-layer performance (i.e., mean permeability, density and strength values, and their respective variances); 2) develop methods for their construction in the field; and 3) develop methods for CQA to ensure that desired performance is achieved.

\subsubsection{Test Description}

The chemical grout barrier component tests are divided into three categories: 1) lysimeter studies, 2) field studies, and 3) long-term stability studies. The work for FY 1988 is detailed below. Activities for FY 1989 through FY 1992 are described but will be detailed more thoroughly in future test plans.

Based on experience of WHC Environmental Technology personnel and the 1 iterature cited in Section 4.1 , a mixture of approximately $33 \%$ sodium silicate solution and McGee soil will be used for the chemical grout barrier component. Sodium aluminate will be used as a setting agent for the chemical grout. The $33 \%$ sodium silicate solution is sufficient to ensure that the consolidated mixture has a low hydraulic conductivity while maintaining an acceptable soil strength. Tests conducted with chemical grout barrier components will have a minimum overburden of $90 \mathrm{~cm}$ of soil to prevent desiccation of the chemical grout.

\subsection{FISCAL YEAR 1988}

\subsubsection{Lysimeter Studies}

The purpose of the lysimeter tests is to evaluate the performance of a chemical grout barrier component under environmental conditions. As in the clay tests, five small-tube lysimeters were installed at the south end of the STLF. The control lysimeters were also established within the STLF. 
Figure 4.1 shows the test configuration. A $15-\mathrm{cm}$-thick coarse layer of pit run gravel (less than $3-\mathrm{cm}$-diameter rock) was placed in the bottom of the lysimeter and covered with a 30-cm layer of the sodium silicate-McGee soil mixture. The chemical grout layer was covered with a $120-\mathrm{cm}$ layer of McGee soil.

All five chemical grout component tests are bare (no vegetation) and are irrigated as needed to maintain twice the average annual rainfall ( $2 X$ normal precipitation). The lysimeters periodically are weighed and the drainage measured to determine barrier performance.

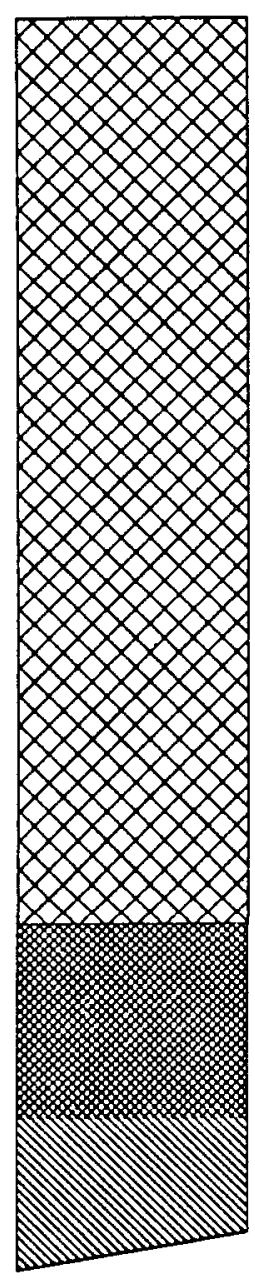

$120 \mathrm{~cm}$ McGee Soil

$30 \mathrm{~cm}$ Chemical

Grout Layer

Pit Run Gravel

FIGURE 4.1. Smal1-Tube Lysimeter Chemical Grout Barrier Component 


\section{$4.4 \quad$ FISCAL YEAR 1989}

\subsubsection{Lysimeter Studies}

The small-tube lysimeters installed in FY 1988 are being monitored to obtain the water balance data required for barrier evaluation.

\subsubsection{Field Studies}

Small-scale field plots $\left(25 \mathrm{~m}^{2}\right)$ will be constructed to 1) test the formulation of the chemical grout-McGee soil mixture developed in FY 1988 and 2) develop the test methods subsequentiy required. The construction of the plots will be similar to the layering placed in the small-tube lysimeters, except that a layer of sand or gravel will be placed directly on top of the chemical grout layer to facilitate excavation for testing. Equipment and methods for obtaining sample cores will be tested in addition to laboratory testing of the cores themselves. The capability to measure in situ hydraulic conductivity with large, double-ring infiltrometers will also be developed. Measurements will be compared with similar measurements made with core samples in the laboratory.

\subsection{FISCAL YEAR 1990}

\subsubsection{Lysimeter Studies}

The small-tube lysimeters installed in FY 1988 will continue to be monitored to obtain the water balance data required for barrier evaluation.

\subsubsection{Field Studies}

A field-scale barrier (similar to that shown in Figure 3.2 ) will be constructed using normal heavy construction equipment to develop construction methods and chemical grout barrier component CQA test methods. We anticipate constructing a $12-\mathrm{in} .(30-\mathrm{cm})$ chemical grout barrier component layer in the field in two or three pours. Ceramic suction lysimeters will be placed both above and below the chemical grout layer to detect possible moisture breakthrough. Five large-scale hydraulic conductivity tests will be conducted on the chemical grout component immediately after construction. A minimum of five additional field hydraulic conductivity tests will be made on various parts of the barrier after construction to evaluate the effects of placing an 
overburden on the layer, along with construction performance and spatial variability of the chemical grout component. After each hydraulic conductivity test, core samples will be taken from the immediate area to measure density and strength. Core holes will be backfilled by hand with material identical to that taken out while placing neutron-gamma access tubes to monitor moisture and density changes in the barrier.

\subsubsection{Long-Term Stability Studies}

Instrumentation placed in the FY 1990 field study barrier will be monitored to establish a baseline for barrier moisture and density values.

\subsection{FISCAL YEAR 1991}

\subsubsection{Lysimeter Studies}

The small-tube lysimeters installed in FY 1988 will continue to be monitored to obtain the water balance data required for barrier evaluation.

\subsubsection{Field Studies}

Data from the FY 1990 field studies (both clay and chemical grout barrier components) and design criteria developed in this program will be used to construct a prototype barrier similar to that described in Sections 3.5.2 and 4.5.2. Hydraulic conductivity, density, and strength measurements will also be conducted as above.

\subsubsection{Long-Term Stability Studies}

Instrumentation placed in the FY 1990 field study barrier will be monitored for significant changes in barrier moisture and density values. The chemical grout component will be excavated to inspect the surface for possible cracks or deformations. After the inspection, hydraulic conductivity tests and coring for strength and density measurements will be conducted.

\subsection{FISCAL YEAR 1992}

\subsubsection{Field Studies}

Construction methods and CQA tests developed in FY 1990 and 1991 will be incorporated into the construction of a large-scale barrier field study. The 
barrier field study facility will be used to test the effects of subsidence on chemical grout barrier components as well as to gather data for calibration and validation of WHC computer transport models, plant root and animal intrusion tests, erosion studies, and barrier performance demonstration.

\subsubsection{Long-Term Stability Studies}

Instrumentation placed in the FY 1990 field study barrier will be monitored for significant changes in barrier moisture and density values. The surface of the chemical grout component will be inspected for cracks or deformations. After the inspection, hydraulic conductivity tests and coring for strength and density measurements will be conducted. 


\subsection{COST ESTIMATES}

Barrier

\section{Asphalt}

Laboratory Tests

Lysimeter Tests

Field Tests

Project Management Subtotal \begin{tabular}{ccc} 
& \multicolumn{2}{c}{ Costs per Year, SK } \\
\hline FY 1988 FY $1989 \quad$ FY 1990 FY
\end{tabular}

1991
Combined

305

125

475

180

1085

Clay

Laboratory Tests

Lysimeter Tests

Field Tests

Project Management Subtotal
0

6

0

$\underline{2} \quad \underline{5}$

8
15

20

25

$\underline{20}$

80

150

50

300

50

325

330

25

20

75

$\underline{25}$

145

25

145

25

20

75

25

145

25

20

75

25

145

25

75

91

Field Tests

Project Management

Subtotal

TOTAL

$0 \quad 0$

8

66
5

25

130

590

615

630

2031 



\subsection{SAFETY AND QUALITY ASSURANCE}

A11 laboratory and field work procedures will be performed using standard PNL and WHC safety practices. Safe working procedures, habits, and conditions will be the first priority of all work. No unusual safety hazards are anticipated during the completion of this work. No toxic or hazardous materials are required by this test plan.

Data will be entered into a series of controlled, bound laboratory notebooks issued by PNL for the PNL work and by WHC for the WHC work. Entries will include notes, design sketches, minor procedural modifications, data, and other relevant information. All entries will be dated and signed, and checked by the responsible task leader. Data collected or transferred to computer disk will be backed-up by a hard copy located in a three-ring binder clearly marked by the number of the corresponding laboratory notebook. In addition to computer files, numerous data sheets will be required for each laboratory and field test of the alternate barriers. These data sheets, containing unreduced data, will be maintained in a three-ring binder clearly marked by the number of the corresponding 1aboratory notebook. Notebooks and three-ring binders shall be maintained at the laboratory or at the office of the task leader. At no time shall the custody of the notebooks or the threering binders be issued to separate individuals.

Instrument (scales, etc.) calibrations will be required during tests. Procedures and data will be documented in the PNL and WHC notebooks. Calibration standards will be traceable to standards sufficient for project needs based on required levels of accuracy. 


\subsection{REFERENCES}

Adams, M. R., and N. R. Wing. 1986. Protective Barrier and Warning Marker System Development Plan. RHO-RE-PL-35P, Westinghouse Hanford Company, Richland, Washington.

Baker, E. G., H. D. Freeman, J. N. Hartley, and G. W. Gee. 1982. "Cost and Effectiveness of Radon Barrier Systems." In Proceedings of the Fifth Symposium on Uranium Mill Tailings Management, pp, 383-395. Civil Engineering Department, Colorado State University, Fort Collins, Colorado.

Baker, E. G., J. N. Hartley, H. D. Freeman, T. E. Gates, D. A. Nelson, and R. L. Dunning. 1984. Asphalt Emulsion Radon Barrier Systems for Uranium Mill Tailings - - An Overview of the Technology. DOE/UMT-0214/PNL-4840, Pacific Northwest Laboratory, Richland, Washington.

Berry, R. M. 1982. "Injectite-80 Polyacrylamide Grout." In Grouting in Geotechnical Engineering, pp. 394-402. American Society of Civil Engineers, New York.

Buelt, J. L. 1983. Liner Evaluation for Uranium Mill Tailings: Final Report. DOE/UMT-0216/PNL-4842, Pacific Northwest Laboratory, Richland, Washington.

Carlson, R. A., 1986. Hydraulic Conductivity and Moisture/Density Relationships of Candidate Packing Material. SD-BWI-TI-203 REV 0, Rockwell Hanford Operations, Richland, Washington.

Caron, C. 1982. "The State of Grouting in the 1980's." In Grouting in Geotechnical Engineering, pp. 346-358. American Society of Civil Engineers, New York.

Clarke, W. J. 1982. "Performance Characteristics of Acrylate Polymer Grout." In Grouting in Geotechnical Engineering, pp. 418-432. American Society of Civil Engineers, New York.

Danie1, D. E. 1987. "Earthen Liners for Land Disposal Facilities." In Proceedings of the ASCE Specialty Conference on Geotechnical Practice for Waste Disposal, June 1986. University of Michigan, Ann Arbor, Michigan.

Danie1, D. E., and S. J. Trautwein. 1986. "Field Permeability Test for Earthen Liners." In ASCE Specialty Conference on Use of In-Situ Tests in Geotechnical Engineering, June 1986. Virginia Polytechnic Institute and State University, Blacksburg, Virginia.

Day, S. R., and D. E. Daniel. 1985. "Hydraulic Conductivity of Two Prototype Clay Liners." J. of Geotech. Engr. 111(8):957-970. 
Ely, R. L. Jr., G. L. Kingsbury, M. R. Branscome, L. J. Goldman, C. N. Northeim, J. H. Turner, and F. O. Mixon, Jr. 1983. Performance of Clay Caps and Liners for Disposal Facilities: Final Report. EPA Contract No. 68-03-3149, Research Triangle Institute, Research Triangle Park, North Carolina.

Fayer, M. J., W. Conbere, P. R. Heller, and G. W. Gee. 1985. Model Assessment of Protective Barrier Designs. PNL-5604, Pacific Northwest Laboratory, Richland, Washington.

Fayer, M. J. 1987. Model Assessment of Protective Barrier Designs: Part 2. PNL-6297, Pacific Northwest Laboratory, Richland, Washington.

Freeman, H. D., J. N. Hartley, and G. W. Gee. 1984. "Radon Barrier FieldTest Monitoring at Grand Junction Tailings Pile." In Proceedings of the Sixth Symposium on Uranium Mill Tailings Management, pp. 277-286. Civil Engineering Department, Colorado State University, Fort Collins, Colorado.

Gee, G. W., M. D. Campbel1, H. D. Freeman and J. F. Cline. 1989. Assessment of Cover Systems at the Grand Junction, Colorado, Uranium Mill Tailings Pile: 1987 Field Measurements. PNL-6750, Pacific Northwest Laboratory, Rich7and, . Washington.

Gee, G. W., J. L. Downs, and M. L. Rockhold. 1989. Status of FY 1988 Soil Water Balance Studies on the Hanford Site. PNL-6750, Pacific Northwest Laboratory, Richland, Washington.

Gee, G. W., J. T. Zellmer, M. E. Dodson, R. R. Kirkham, B. E. Optiz, D. R. Sherwood, and J. Tingey. 1981. "Radon Control by Multilayer Earth Barriers, 2. Field Tests." In Proceedings of the Fourth Symposium on Uranium Mill Tailings Management, pp. 289-308. Civil Engineering Department, Colorado State University, Fort Collins, Colorado.

Hartley, J. N., G. W. Gee, E. G. Baker, and H. D. Freeman. 1983. 1981 Radon Barrier Field Test at Grand Junction Uranium Mill Tailings Pile. PNL-4539, Pacific Northwest Laboratory, Richland, Washington.

Hartley, J. N., G. W. Gee, H. D. Freeman, J. F. Cline, P. A. Beedlow, J. L. Buelt, J. F. Relyea, and T. Tamura. 1982. "Uranium Mill Tailings Remedial Action Program (UMTRAP) Cover and Liner Technology Development Project." In International Symposium on Management of Wastes from Uranium Mining and Milling, pp. 429-448, ATbuquerque, New Mexico. IAEA-SM-262/39, International Atomic Energy Agency.

Hartley, J. N., P. L. Koehmstedt, D. J. Esterl, H. D. Freeman, J. L. Buelt, D. A. Nelson, and M. R. Elmore. 1980. Asphalt Emulsion Sealing of Uranium Mi11 Tailings 1979 Annual Report. PNL-3290, Pacific Northwest Laboratory, Richland, Washington. 
Hartley, J. N., P. L. Koehmstedt, D. J. Esterl, H. D. Freeman, J. L. Buelt, D. A. Nelson, and M. R. Elmore. 1981. Asphalt Sealing of Uranium Mill Tailings 1980 Annual Report. PNL-3752, Pacific Northwest Laboratory, Richland, Washington.

Herzog, B. L., K. Cartwright, T. M. Johnson, and H.J.H. Harris. 1982. A Study of Trench Covers to Minimize Infiltration at Waste Disposal Sites. NUREG/CR-2478, I1linois State Geological Survey, Champaign, I11inois.

Karp, K. E. 1986. Covers Monitoring at the Grand Junction Tailings Piles: A Progress Report for the Period July 1985 Through September 1985. Bendix Field Engineering Corporation, Grand Junction Operations, Grand Junction, Colorado.

Kleppe, J. H., and R. E. 01son. 1985. Desiccation Cracking of Soil Barriers, Hydraulic Barriers in Soil and Rock, pp. 263-275, eds. A. I. Johnson, R. K. Frobel, N. J. Cavalli, and C. B. Peterson. ASTM STP 874, Philadelphia.

Koehmstedt, P. L., J. N. Hartley, and D. K. Davis. 1977. Use of Asphalt Emulsion Sealants to Contain Radon and Radium in Uranium Tailings.

BNWL-2190, Pacific Northwest Laboratory, Richland, Washington.

LeMaire, G. W. 1953. "A Study of Asphalts and Asphaltic Materials." Quarterly Colo. School Mines 48(2):1.

Marschner, R. F. 1980. "Lowly Asphalt Comes into Its Own." Field Museum of Natural History Bulletin 51(10):4-9.

Micropaedia. 1974. "Asphalt." In The New Encyclopedia Britannica, Vol. 36, p. 588. Encyclopedia Britannica Inc., Chicago.

Pusch, R. 1983. Stability of Deep-Sited Smectite Minerals in Crystalline Rock - Chemical Aspects. SKBF/KBS TR 83-16, Karnbarnsleskerhet, Stockholm.

U.S. Department of Energy (DOE). 1987. Disposal of Hanford Defense HighLevel, Transuranic and Tank Wastes. Final Environmental Impact Statement. DOE/EIS-0113, U.S. Department of Energy, Washington, D.C.

U.S. Environmental Protection Agency (EPA). 1978. "Hazardous Waste. Guidelines and Regulations and Proposal on Identification and Listing." Federal Register 43(243):58946-59026.

U.S. Nuclear Regulatory Commission (NRC)-U.S. Environmental Protection Agency (EPA). 1987. Joint NRC-EPA Guidance on a Conceptual Design Approach for Commercial Mixed Low-Level Radioactive and Hazardous Waste Disposal Facilities. Letter to States, Compact Regions and all NRC Licensees. August 1, 1987. U.S. Nuclear Regulatory Commission and U.S. Environmental Protection Agency, Washington, D.C. 



\section{DISTRIBUTION}

No. of

Copies

OFFSITE

2 DOE/Office of Scientific and Technical Information

\section{ONSITE}

7 DOE Richland Operations Office

G. J. Bracken

J. J. Broderick

R. D. Freeburg

R. E. Gerton

R. D. Izatt

S. M. Prestwich

G. W. Rosenwald

27 Westinghouse Hanford Company

M. R. Adams

L. C. Brown

J. W. Cammann

R. A. Carlson

H. F. Daugherty

K. A. Gasper

W. F. Heine

J. M. Henderson

G. W. Jackson

K. N. Jordan

D. S. Landeen

R. E. Lerch

H. E. McGuire

K. W. Owens

K. L. Petersen

S. J. Phillips

J. F. Relyea

R. C. Roos
No. of

Copies

R. C. Routson

H. W. Schulz

D. A. Turner

S. A. Weigman

N. R. Wing

D. D. Wodrich

R. Wojtasek

D. E. Wood

40 Pacific Northwest Laboratory

L. L. Cadwell

M. D. Campbel1

D. A. Cataldo

J. W. Falco

M. J. Fayer

M. G. Foley

H. D. Freeman (10)

G. W. Gee (2)

T. L. Jones

C. T. Kincaid

R. R. Kirkham

D. C. Klopfer

G. V. Last

M. W. Ligotke

S. 0. Link

W. H. Rickard

L. E. Rogers

R. L. Skaggs

J. A. Stottlemyre

C. P. Streile

M. E. Thiede

J. M. Thomas

W. J. Waugh

R. E. Wildung

Publ ishing Coordination

Technical Report Files (5) 
. . 